\title{
Marka Tanınırlığının Ötesine Geçen Maskot: Eddie The Head
}

\author{
Mascot Beyond Brand Recognition: Eddie The Head
}

\author{
Murat KARA \\ Burdur Mehmet Akif Ersoy Üniversitesi, Sanat ve Tasarım Fakültesi, Görsel İletişim Tasarımı Bölümü, \\ muratkara@mehmetakif.edu.tr \\ ORCID Numaraları | ORCID Numbers: 0000-0002-7285-887X
}

\begin{abstract}
Öz: Üretim teknolojilerinin gelişmesi ve ekonomik kapasitelerin artışı üretim kolaylığını sağlarken çok sayıda ürün veya hizmet alternatiflerinin ortaya çıkmasına sebep olmuş, böylece markaların reklam ve pazarlama gibi alanlarda rekabet etme zorunluluğu oluşmuştur. $\mathrm{Bu}$ rekabet ortamında, ürün, hizmet ya da farklı biçimlerde ortaya koyulan yapıtların hedef kitlesine ulaşırken benzerlerinden ayrışması ve daha çok tercih edilmesi amaciyla markalar çeșitli pazarlama stratejilerine ihtiyaç duyar hale gelmiștir. Marka olușumu ve gelișiminde kullanılan reklam ve pazarlama araçlarından biri olan maskotlar da marka imajını güçlendiren ve markanın kişiliğini yansıtan hayali ya da gerçek karakterler olarak karşımıza çıkmaktadır. Bu çalısmada, markalara ait bir reklam unsuru olarak tasarlanan maskotların doğru bir pazarlama stratejisi sonucu kazandığı popülerlik üzerinde durularak, tanınırlık bakımından markadan bağımsız hale gelmesi, şöhretli ve değerli bir imgeye dönüşmesinden bahsedilmektedir
\end{abstract}

Anahtar Kelimler: Marka, Markalaşma, Maskot, Kimlik, Metal Müzik

Abstract: While the development of production technologies and the increase in economic capacities provide ease of production, many product and service alternatives have emerged and thus, brands have had to compete in areas such as advertising and marketing. In this competitive environment, brands need various marketing strategies in order to differentiate their products from their counterparts and become more preferred when they reach their target audience. Mascots, which are one of the promotional tools used in the formation and development of the brand, appear as characters that strengthen the brand image and reflect the personality of the brand. In this study, it is focused on popularity of mascots which is gained as a result of an accurate marketing strategy, mentioned to become independent of the brand and to become famous and valuable image.

Keywords: Brand, Branding, Mascot, Identity, Metal Music 


\section{GİRIŞ}

Üretim teknolojilerin gelişmesine ve ekonomik kapasitelerin sürekli olarak büyümesine paralel olarak ticari rekabetin arttığ 1 küresel dünya pazarında çok çeşitli alanlardan kurum ya da kişiler belirli işaret, kısaltma, renk veya isimleri kullanarak marka yaratma eğilimindedir. Temel anlamda, ortaya konan ürün ya da hizmetin hedef kitlesine ifade ediliş biçimi olarak da tanımlanabilen marka, günümüz koşullarında benzerlerinden ayırt edilebilmesi ve hedef kitlenin hafızasında kalıcı olabilmesi dolayısıyla ticari bakımdan önemli bir role sahiptir (Yamankaradeniz, 2007, s.10).

Nitelik bakımından markanın yer aldığı sektörde benzerlerinin olması, kalite ölçütlerinin birbirine yakınlaşması ve üretim kolaylığı sonucu meydana gelen arz fazlalığı, tercih edilme kaygısına yol açmakta, bu nedenle ürün veya hizmetler arasındaki rekabet artmaktadır. Marka yaratmak, markalaşmak ya da var olan markanın değerini arttırmak ustaca düşünülmüş stratejiler gerektirmektedir. Markanın yer aldığı sektördeki sürdürülebilir başarısı ve arzu edilen ekonomik getirileri ancak doğru planlanmış pazarlama stratejileri ile mümkündür. Bu bağlamda marka, hedef kitlenin satın alma eğilimlerini etkilemeli ve onlarda güven hissi uyandırmalıdır. Ortaya koyduğu ürün ya da hizmetin kalite istikrarını da sağlayan markaların zaman içerisinde hedef kitlesiyle olan bağ 1 güçlenir ve daha çok tercih edilmesi sonucunda değeri artar.

Marka, rekabet ortamında tüketiciye ayırt edici bir özellik sunarken ürün veya hizmetin işlevsel yararına somut, diğer pek çok açıdan yarattığı değerler bakımından da soyut niteliğe sahip bir pazarlama unsurudur (Uztuğ, 2002, s.22). Pazarlama ilişkilerinde hedef kitle olarak da adlandırılabilecek olan tüketici, temel ihtiyaçlarının yanı sıra sosyal, kültürel ve psikolojik açılardan tatmin olma arzusundadır. Marka ve markanın hedef kitlesinin karşılıklı çıkar ilişkisi üzerine kurulu olduğu düzende marka maddi beklentiler içerisindeyken tüketici tarafında aidiyet, onaylanma ve sosyal statü kazandırma gibi unsurlar tercih etme sürecinde önem teşkil etmektedir (Can, 2007, s.226). Bu bakımdan markalar nitelik anlamlarını tüketiciye aktararak onlarda ayrıcalıklı olma hissi yaratır ve bu da markanın uzun vadeli tercih edilirliğine katkı sağlaması bakımından önemlidir. Nitelik anlamlar beraberinde sembolik bir değer getirirken, markayı benimseyen tüketiciye kendini ifade edebilme olanağı sunar ve bunun sonucunda marka ile tüketici arasında daha güçlü bir iletişim gerçekleşir. Öte yandan, bir markanın hedef kitlesine iletebileceği diğer anlam düzeyleri de vardır. Bhat ve Reddy (1998), nitelik anlamı ile beraber bir markada değer, yarar ve kişilik anlamlarının da olması gerektiğini belirtmektedir (1998, s.40). Nitekim, markanın nitelik anlamlarının meydana getirdiği değer ve itibar, tüketici nezdinde işlevsel bir yarara dönüşmediği sürece anlamsız kalacak ve güçlü bir marka kişiliğinin oluşmasını engelleyecektir. Bu yüzden, sözü edilen dört anlamın doğru bir biçimde oluşturulması için birbirleriyle bağlantılı bir strateji izlenmesi gerekmektedir.

Güçlü ve değerli bir marka oluşturulması için gerekli olan tüm pazarlama unsurları tüketicinin kendini yakın hissedebileceği bir kişilik yaratmalı, bu kişilik ise tüketiciyi tatmin eden en doğru duygu ve düşünceleri içermelidir (Özcan, 2014, s.55). Böylelikle, marka kişiliği ve tüketici kişiliği uyumlu bir biçimde olgunlaşarak uzun süreli bir pazarlama ilişkisine yol açabilecektir.

$\mathrm{Bu}$ çalışmada, markaların oluşum ve sonrasındaki gelişim sürecinde marka kişiliğini güçlendiren, tüketici veya hedef kitle ile duygusal bağ kurmaya yarayan marka maskotları incelenerek bilinirlik ve değer açısından yerleştikleri konum örneklerle açıklanmaya çalışılmıştır. Ayrıca, verilen örneklerde ürün/hizmet ve tüketici ilişkisinin yanı sıra sanat yapıtları ve hitap ettiği kitle arasındaki pazarlama ilişkisi de ele alınmaktadır.

\section{Marka Kișiliğinin Olușumunda Maskotların Rolü}

Ürün, hizmet ya da bir sanat yapıtı ortaya konulurken bunlardan yararlanacak olan kitle tarafından kabul edilebilir bir marka kimliği oluşturmak çok önemlidir. Sürekliliğin ve tutarlılığın olduğu bir marka kimliği var olduğu sürece marka kişiliğinden de bahsetmek mümkün olabilir.

Marka kişiliği; semboller (amblem, logo, logotayp vb.), aktarımlar, yaşam biçimi ve karakter gibi unsurlardan meydana gelmektedir (Örendirek, 2006, s.6). Markanın temel yapısını oluşturan somut ve soyut unsurların bir parçası olan marka kişiliği, markayı tanımlayan, markanın kitlesine belirli mesajlar veren ifade ediliş biçimi olarak tanımlanabilir. Marka kişiliğine, tıpkı insan karakteri gibi özellikler yüklenerek, duygu ve düşüncelere sahip bir organizma gibi algılanması sağlanır. Pazarlama 
ilişkilerinde duygusal bağın oluşumunu sağlayan marka kişiliği, markanın oluşum sürecinin en önemli parçalarından biri olarak varsayılmaktadır.

İnsana dair karakter ve kişilik özelliklerinin markaya yüklenmesi ile oluşan marka kişiliği çeşitli görsel tasarım elemanları ile somutlaşır ve hitap edilen kitlenin zihninde hatırlanabilir bir imgeye dönüşür. Genellikle biçim, yazı ve renk gibi grafik elemanlardan oluşan bu imgelerin hafızada istenilen etkiyi yaratması ve hedef kitlede ilgi uyandırması amacıyla, dikkat çekicilik, yenilik, canlılık gibi çeşitli özelliklere sahip olması gerekmektedir (Bettinghaus ve Cody, 1994, s. 223). Sözü edilen bu imgeler, dikkat çekici ve ayırt edici özellikleri ile markaya olan ilginin sürekliliğini sağlarken özgün bir karakter yapısına sahip biçimleri ile markanın benzerlerine kıyasla daha farklı görünmesini amaçlar. Marka kişiliği oluşturulurken grafik imgelerde kullanılan samimi ve hedef kitlenin beklentilerine uygun tasarım dili hiç şüphe yok ki karşı tarafta bir benimseme duygusu yaratmaktadır. Ancak, bu imgeler dışında pazarlama ilişkilerinde marka kişiliğinin oluşumuna katkı sağlayan ve yalnızca markaya özgü tasarlanan karakterler karşımıza çıkmaktadır. İlgi çekici görüntü ve davranışları ile markayı diğer markalardan ayrıştıran, markanın kimliğini güçlendiren ve ona saygınlık kazandıran bu karakterler maskot olarak tanımlanmaktadır (Özcan, 2014, s.54).

Uğur getireceğine inanılan çeşitli figürler, nesneler veya genel bir deyişle totem olarak da adlandırılan maskotun geçmişi antik dönemlere kadar uzanmaktadır. Masco sözcügüünden türeyerek günümüze kadar gelen maskot kelimesinin ilk kullanımının 1882 yılında ABD'de sahne alan "The Mascot" adlı operada olduğu bilinmektedir (İlisulu, 2011, s.156). Pazarlama iletişiminin güçlenmesi ve yaygın etkinin artırılması için kullanılan maskotlar marka bilinirliğine katkı sağlarken belirgin bir marka imajı da oluşturmaya yardımcı olurlar. Diğer yandan, maskotlar marka kişiliğinin olgunlaşması, markahedef kitle ilişkisinin güncelliğini koruması, markanın benzerlerinden farklılaşması ve markanın hukuki açıdan korunmasında büyük önem taşımaktadır (Çevikbaş, 2007, s.74).

Marka maskotları yaratılırken dikkat edilmesi gereken en önemli husus güvenilirlik ve inandırıcılıktır. Yaratılan maskot insani kusurlar taşıyor olsa bile, marka sayesinde bu kusurlarını gidermeli ve samimi bir görüntüye bürünmelidir. Duygusal açıdan hedef kitlesi ile bağ kuramayan, anlatacak bir hikayesi olmayan ve beklentileri karşılamaktan uzak kalan maskotlar uzun vadede başarılı olamaz, dolayısıyla marka kişiliğine katkı sağlayamazlar.

Genellikle insan, hayvan ve nesnelerin bir karakter haline dönüştürülmesi veya fantastik unsurlar taşıyan figürler biçiminde çeşitli sektörlerde kullanım alanı bulan maskotlar, ürün, hizmet ya da bir sanat yapıtının tanıtımı yapılan mecralarda markanın görünen yüzüdür. Çoğu zaman çizgi kahramanlar olarak tasarlansalar da bazen gerçek hayattan bir figür de marka maskotu olarak kullanılabilmektedir. Ancak, bu şekilde yaratılan maskotlar marka için bazı riskler taşımaktadır. Yaşayan bir figürün özel hayatında karışacağı olumsuz bir olay markanın kişiliğine ve itibarına zarar verebilir. Hayal ürünü olarak ortaya konan bir maskot ise tamamen kontrol altındadır ve yapacağ tüm eylemler marka kişiliğine uygun olarak planlanır. Bu yüzden, markalar çoğunlukla gerçekte var olmayan, yaşamayan ve yaşlanmayan bir karakterle reklam ve tanıtım faaliyetlerini sürdürerek, markanın uzun yıllar sürecek devamlılı̆̆ını ve tutarlılığını sağlama eğilimindedir.

Tüm bu sözü edilen gereksinimlere uygun olan maskotlar zamanla pazarlama ilişkisinde hedef kitle için vazgeçilmez bir unsur haline gelir. Buna ek olarak, başlangıçta bir markaya ait pazarlama aracı olarak tasarlanan maskotlar, süreç içerisinde markanın değerini arttırırken hedef kitlenin gözünde tek başına bir figür olarak da değer ve anlam kazanır, bağlamından uzaklaşarak çok farklı bir konumda ve özerk bir yapı halinde karşımıza çıkabilir.

\section{Markadan Daha Değerli Konuma Gelen Maskotlar}

Bir markanın başarılı olabilmesi için gerekli olan reklam ve tanıtım faaliyetleri belirli bütçe ihtiyacını doğurmaktadır. Aynı şekilde bir markanın tanıtıcı yüzü olarak seçeceği maskotun herkes tarafından bilinir hale gelmesi de bütçe ile doğru orantılıdır. Bu yüzden, markanın tutunması ve bilinirliğinin sürekli hale gelmesi için gerekli olan maddi gereksinimler, büyük sermayeye sahip firmaları öne çıkarmaktadır. Markaya ait herhangi bir ürün ya da hizmeti tanıtan maskotların çeşitli mecralarda sürekli görünür olma gerekliliği diğer tüm reklam stratejilerinde olduğu gibi maskotun benimsetilmesi konusunda da ekonomik gücün önemini ortaya koymaktadır. Özellikle televizyon 
reklamlarına bakıldığında çok uluslu ya da piyasa değeri çok yüksek olan dünya çapındaki firmaların maskot kullanımını tercih ettiği görülmektedir.

Markaların farklılaşma çabası ile ortaya koydukları tüm pazarlama stratejilerinin amacı hedef kitle ile uzun süreli ve güçlü bir bağ kurmaktır. Markanın pazarlama ilişkilerindeki satın alma sürecinde tercih edilmesine olanak sağlayan ve markanın benimsediği kişiliği temsil eden maskotların markalar için kullanılmaya başlanması 1800'lü yılların sonlarına kadar uzanmaktadır. Michelin adını taşıyan dünyaca ünlü lastik üreticisi firmanın kurucularından çıkan fikri çizgiye dönüştüren O'Galop, bilinen ilk marka maskotunu tasarlamıştır (İlisulu, 2011, s.157). "Bibendum" olarak bilinen bu maskot onlarca y1l içerisinde sayısız mecrada, pek çok tanıtım materyalini süslemiş ve günümüzde firmanın sahip olduğu değere yaptığı katkının yanı sıra dünyanın en çok tanınan figürlerinden biri haline dönüşmüştür (Resim 1).

Sanrio adlı şirketin Yuko Shimizu'ya tasarlattığı ve Japon popüler kültürünü yansıtan bir karakter olarak karşımıza çıkan "Kitty White", bilinen diğer adıyla "Hello Kitty" ilk görücüye çıktığı 1976 yılından bu yana milyarlarca dolarlık piyasa değerine ulaşmıştır. Maskotun bağlı olduğu kuruluştan bağımsız olarak elde ettiği şöhret onu dünyanın dört bir yanında hayranları olan bir pazarlama fenomenine dönüştürmüştür. Ancak, binlerce ürün çeşidinin marka yüzü olan bu karakterin asıl olarak hangi ürünü temsil ettiğgi çoğu insan tarafindan bilinmemektedir (Resim 2). Her yaştan kadın grubunun tercih ettiği bir marka kişiliğini meydana getiren Hello Kitty karakteri, markadan bağımsız olarak üretilen oyuncaklar, tekstil ürünleri, kırtasiye malzemeleri, müzik aletleri, mücevherler ve hatta uçak üzerine giydirme biçiminde akla gelebilecek her yerde kullanılır hale gelmiştir. Şüphesiz ki, maskotun tasarımı ve pazarlama stratejisi bu başarıda önemli bir rol oynamaktadır (Servant, 2016).

Sinemaya ilgisi olan ya da olmayan herkesin yaşamında en az bir kere karşılaşmış olabileceği kükreyen aslan "Leo" sinema tarihine damga vurmuş bir maskot olarak karşımıza çıkmaktadır (Resim 3). Başlangıçta bir logo olarak tasarlanan Leo Maskotu ilerleyen dönemlerde onlarca filmin başlangıcında boy göstermiş, görüntüsü ve sinemanın sesli hale gelmesinden sonra duyulan kükreme sesiyle tanınır hale gelmiştir (Sea, ty.). Öyle ki, ortaya çıkışının üzerinden bir asır geçmesine rağmen izleyicilerin hafizasında yer etmeye devam etmektedir. Özellikle siyah-beyaz dönemdeki filmlerin sembolü haline gelen maskot, pek çok filmden, aktör ve aktristen hatta temsil ettiği film şirketinden daha fazla bilinen bir ikondur. Film şeritlerinden oluşan kurdelelerin içerisinde görünen aslan başı pek çok logo tasarımına ilham kaynağı olmuş, defalarca parodi biçiminde ele alınmış ve sinemanın kült imgeleri arasındaki yerini almıştır.

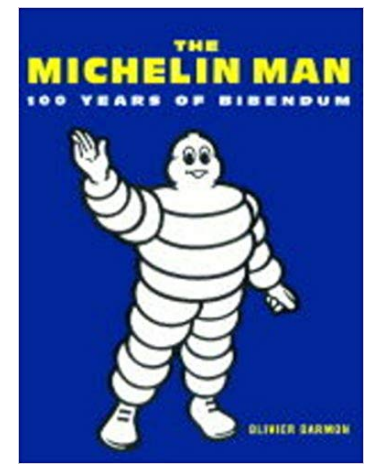

Resim 1: Michelin firmasinın "Bibendum" adlı maskotu

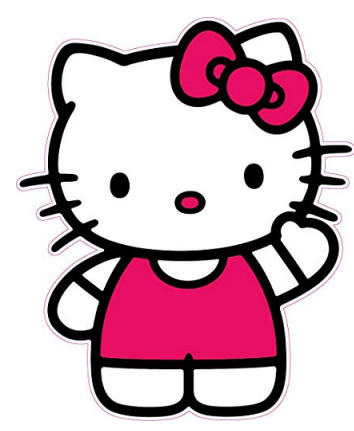

Resim 2: "Hello Kitty" Maskotu

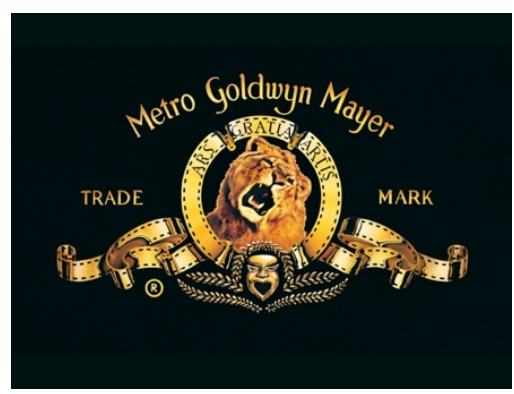

Resim 3: MGM Stüdyolarının Aslan Maskotu "Leo"

Verilen örneklerin yanı sıra, bir markayı temsil etmek için tasarlanan ancak daha sonra markanın bilinirliğinin ötesine geçen nice maskotlardan bahsetmek mümkündür. Yer aldığı çizgi dizinin dışında pek çok farklı ürün üzerinde yer alan ve tembelliğin dünya üzerindeki simgesi haline gelen Garfield, yetişkin ya da çocuk yaştaki bireylerin ilgisini çekmeyi başarabilen Minionlar, Pokemon adlı çizgi filmin ana karakteri olmasına rağmen sayısız sektörde ürün üzeri görsel tasarım elemanı olarak kullanılan Pikachu, Walt Disney'in Mickey Mouse'u gibi maskota dönüşmüş karakterler bunlara örnek olarak 
verilebilir. Öte yandan, bir ürün ya da hizmeti temsil eden marka maskotlarının yanı sıra sanatçı ve sanat yapıtlarını karakterize eden maskotlar da vardır. Özellikle çeşitli müzik türlerinde üretim yapan grupların dinleyici kitlesinde bir aidiyet yaratma arzusuyla tasarlanan bazı maskotlar dünya genelinde kabul görmüş ve marka bilinirliğinin üzerine çıkmayı başarabilmiştir.

\section{Metal Müziğin İmgesi Eddie The Head}

Belirli bir dine, etnik kimliğe, ulusa ya da gruba ait müzik türleri var olsa da evrensel değerlere hitap eden ve tüm insanlığın kabullenebileceği nitelikler taşıyan müzik türleri de mevcuttur. Modern yaşamın getirilerinden biri olan evrensellik aynı beğenilere sahip insan topluluklarını bir araya getirerek ortak bir kimlik oluşturmalarını ve kendi farklılaştırıcı unsurlarını icat etmelerini sağlar (Çerezcioğlu, 2013, s.20). Klasik müzik, halk müziği, pop müzik, etnik müzik, rock ve metal müzik gibi türler farklı kişilik özelliklerini temsil eden birer aidiyet merkezi olarak kabul edilebilecek unsurlardır. Günümüzde temel nitelikleri birbirine benzeyen, ancak bireyin kişiliğini yansıtıcı farklılıklar barındıran müzik türleri çeşitli gruplara hitap eder duruma gelmiştir.

Geçtiğimiz yüzyılın ikinci yarısından itibaren ortaya çıkan müzik grupları ya da bireysel müzik üreten sanatçılar ortaya koydukları eserlerin kişiliğini yansıtabilecek en az kendileri kadar popüler hayal ürünü karakterler kullanmaya başladılar. Daha çok metal ve punk türünde müzik icra eden grupları temsil eden maskotlar dinleyici kitlesiyle güçlü bir bağ kurmak adına konserlerde, albüm kapaklarında, video kliplerde ve grupların lisanslı ürünlerinde (tişört, şapka, poster vb.) boy gösterir oldular (Kayıran, 2015).

Müzik gruplarının benimsediği kişiliğe ait özellikler barındıran maskotlar, hayranların kendini ifade edebildiği, onlarda aidiyet duygusu uyandıran ve yaşam biçimlerine yön veren vazgeçilmez bir arkadaş, bir imge haline geldi. Özellikle 1980 ve 90'lı yıllarda dünya çapında büyük şöhret yakalayan metal müzik gruplarından Megadeth'in Rattlehead'i, Motorhead'in Snaggletooth'u, ve Dio'nun kırmızı gözlere sahip şeytansı Murray maskotu yaygın olarak tanınan karakterlerdi.

Müzik gruplarını temsil eden maskotlar geçmiş dönemlere göre günümüzde daha az kullanılsa da Gorillaz, Radiohead ve Manga gibi gruplar pazarlama stratejilerinde maskot kullanmayı tercih etmektedirler. Ancak, elde ettiği şöhret bakımından bu karakterlerden ayrışan ve Iron Maiden adındaki heavy metal grubunun tüm albüm kapaklarında yer alan Eddie The Head'den ayrıca bahsedilmesi doğru olacaktır.

Esin kaynağı konusunda farklı anlatımları olan Eddie, Iron Maiden'ın kuruluşunun ilk yıllarındaki performanslarında sahne arkasına astıkları bir maske biçiminde görünmekteydi (Resim 4). Daha sonraları grubun görünürlük faaliyetlerini yürütmesi için anlaştığı illüstratör Derek Riggs, bu karakteri bir dergide gördügü ölü asker kafası fotoğrafından yola çıkarak o dönem İngiltere'de popüler olan punk müziği icra eden bir gruba uygun olacağını düşünerek tasarladığını dile getirmiştir (Discosyconciertos, 2014) (Resim 5). Bir diğer kaynak ise Eddie'nin grup üyelerinin kendi aralarında anlattığı bir fikradaki vücutsuz doğan Edward karakterinden ilham alınarak tasarlandığını belirtmektedir (Maiden-world, t.y.). Nitekim, Derek Riggs tarafindan tasarlanarak bir karaktere dönüştürülen Eddie ilk olarak grubun "Running Free" albümünün kapağında görücüye çıkmıştır (Resim 6). 


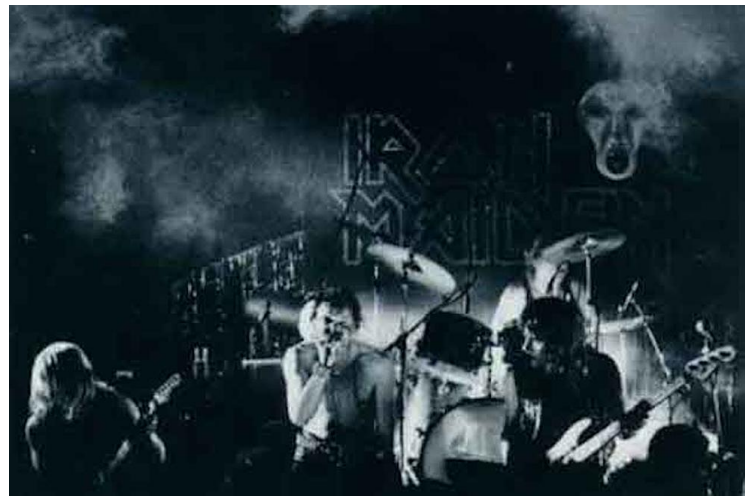

Resim 4: Grubun ilk döneminde gerçekleştirdiği sahne performanslarında arka planda görülen kurukafa maskesi

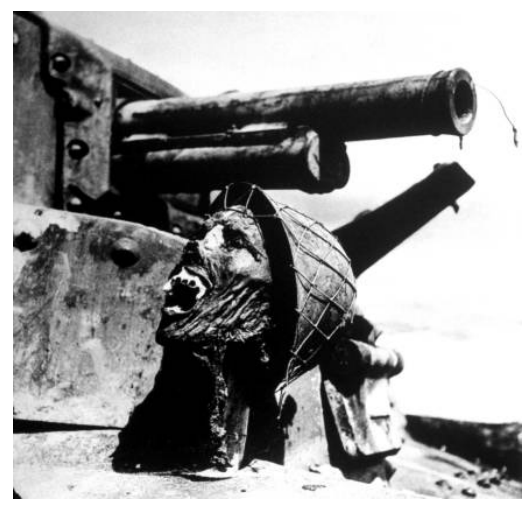

Resim 5: Derek Riggs'in Eddie karakterine ilham verdiğini belirttiği fotoğraf

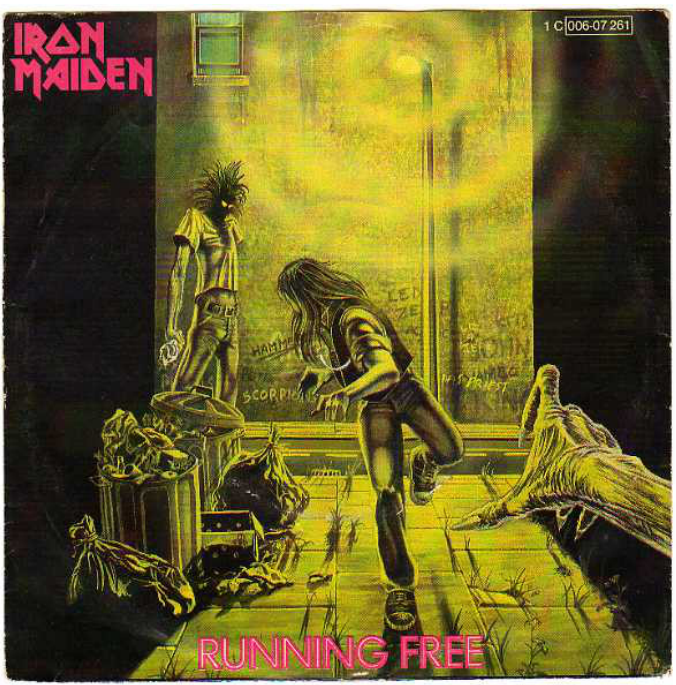

Resim 6: Eddie'nin yer aldığg ilk albüm kapağg

Ürkütücü bakışları ve kafa derisi soyulmuş ancak saçları olan bir kurukafa biçiminde tasvir edilen maskot, grubun turnelerinde gösterdiği sahne performanslarında kukla biçiminde yer almaya başlamıştır. Sahne gösterilerinde en az müzisyenler kadar ön planda olan karakterin hareketleri izleyiciler tarafından beğenilmiş ve konserlerin vazgeçilmezi haline gelmiştir. Öyle ki, grubun dünyanın dört bir yanında verdiği konserlerinde tasarlanan sahne temaları çoğunlukla Eddie'ye ait bir hikâyeyi betimlemiştir.

Gün geçtikçe artan popülerliği ile maskot grubun en büyük pazarlama unsuru olmuştur. Pek çok tanıtım ve reklam materyalinde grup üyelerinin yerine maskot görünür kılınmış ve marka kişiliği onun üzerinden yürütülür hale gelmiştir (Ross, 2006). Yıllar içerisinde grubun çıkarttığı her yeni albümde yer alan söz ve müziklere uygun olarak tasarlanan temalar dahilinde albüm kapağını süsleyen karakter, mumya, gelecekten gelmiş bir robot, cephede savaşan bir asker, şeytana karşı mücadele eden bir savaşçı veya bir zombi gibi resmedilmiştir. Karakter, tasarlanan bu albüm kapağı temalarından dolayı bazen sansasyon yaratmış bazen de yasaklanmıştır (Resim 7). 


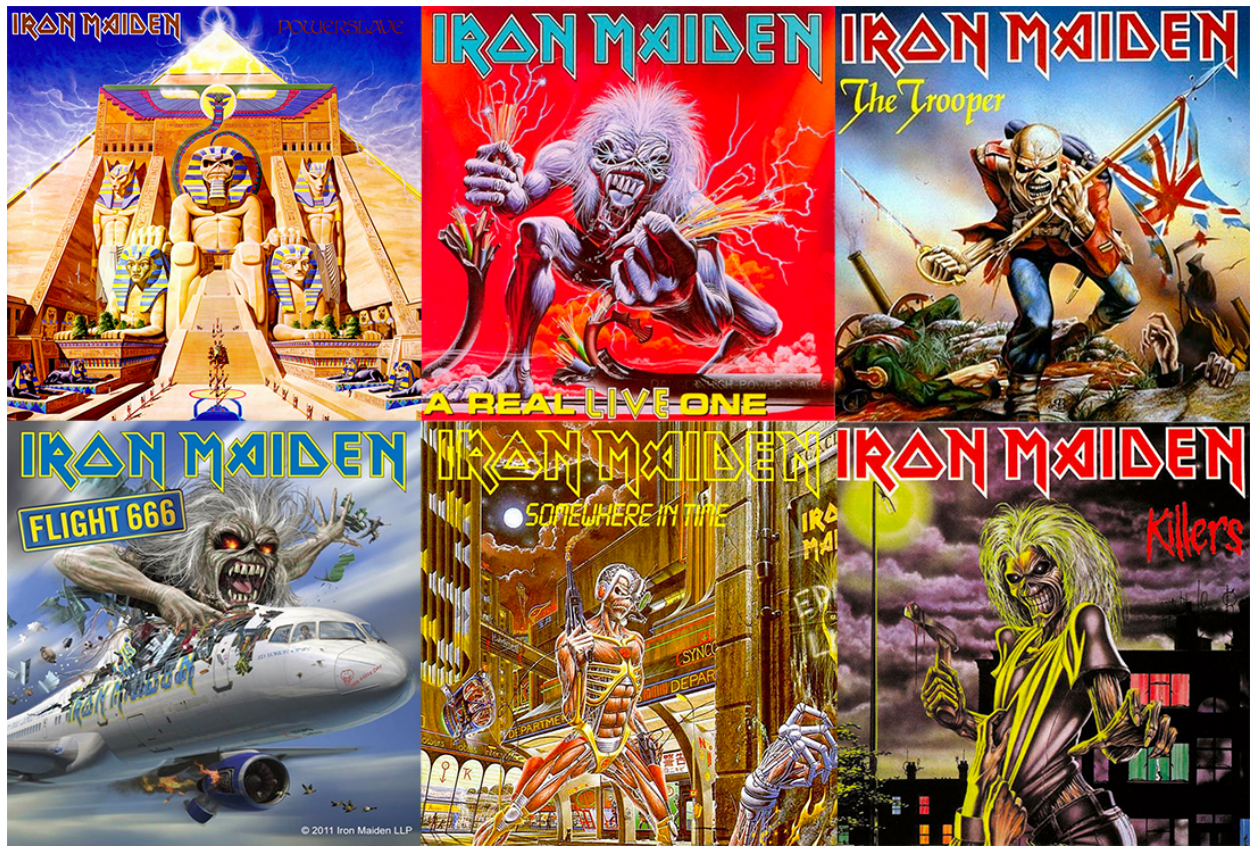

Resim 7: Iron Maiden'ın farklı temalar dahilinde Eddie’yi kullandığı bazı albüm kapaklarından örnekler

40 yıla yakın süredir Iron Maiden'ın maskotu olarak kullanılan ve dünyanın dört bir yanındaki müzikseverlerin yakından tanıdığı karakterin yer aldığı ürün yelpazesi çok geniştir. Grubun müzik icrası ile elde ettiği gelirlerin yanı sıra maskotun yer aldığı onlarca farklı ürünlerden gelen telif hakları ekonomik açıdan gruba büyük katkı sağlamıştır. Aslen temsil ettiği grubun üyelerinden ve belki de grubun adından bile daha çok tanınan bu karakterle dünyanın herhangi bir ülkesindeki pazarda satılan tişörtün üzerinde, bir promosyon ürününde, isyankâr yaşam tarzını benimsemiş bir bireyin vücudunda dövme ya da aksesuar biçiminde, hatta bir askeri birliğin sancağında bile karşılaşılabilir (Daniels, 2016, s.97). Onlarca y1l geçmesine rağmen günümüzde halen grubun tüm görünürlük faaliyetlerinde kullanılmaya devam eden, afişlerini süsleyen, konserlerinde sahne alan ve daha pek çok mecrada sıklıkla görülen maskotun ana karakter olduğu dijital oyunlar, çizgi diziler de bulunmaktadır (Resim 8).
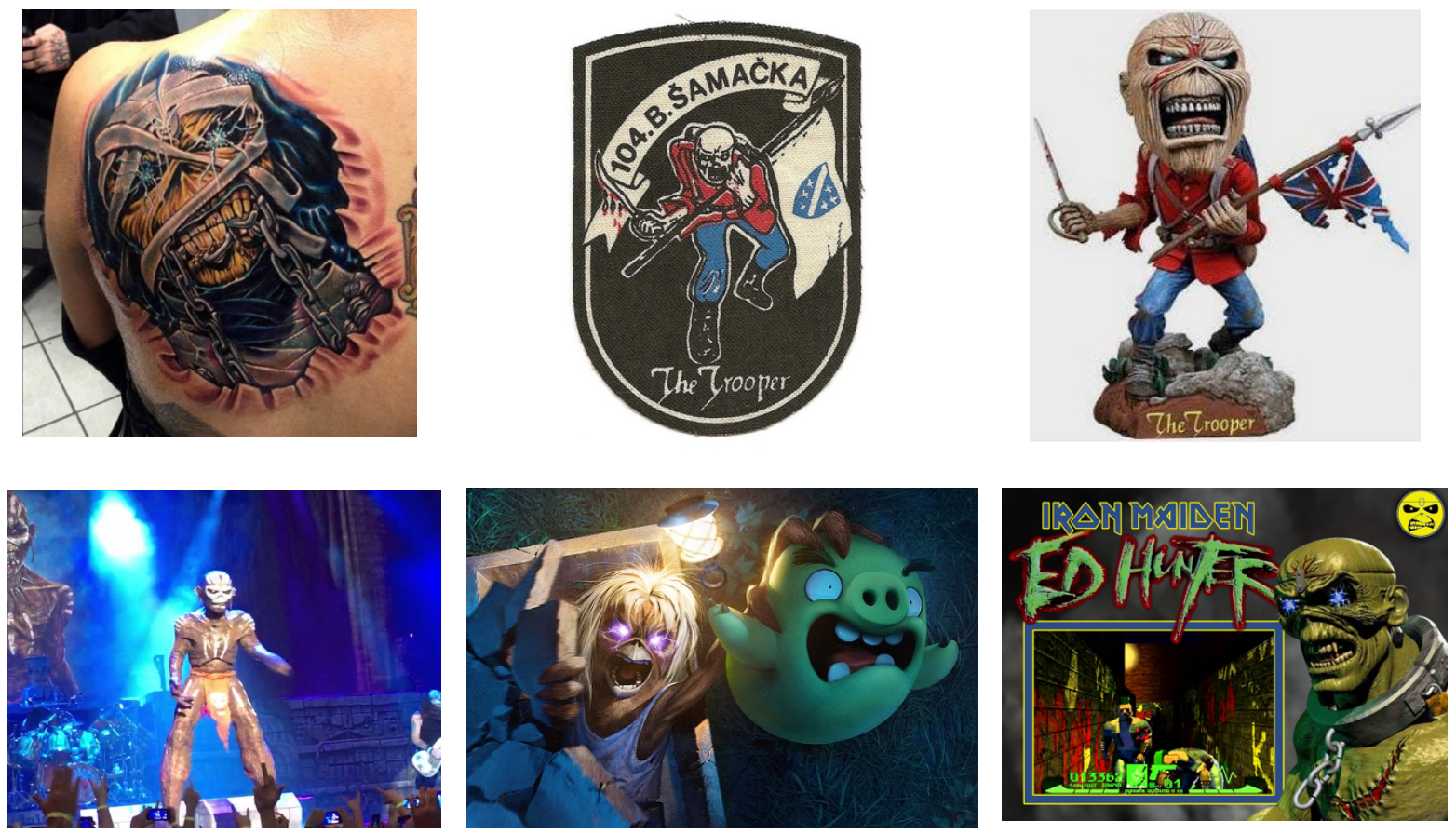
Resim 8: Maskotun farklı mecralarda ve biçimlerde kullanıldığını gösteren örnekler

Bir heavy metal grubunun pazarlanması için tasarlanan "Eddie" elde ettiği şöhret ile marka kişiliğinin sınırlarını aşmış, hitap ettiği kitlenin benimsemesinin de ötesinde tüm dünyada metal müziği temsil eden bir maskot, bir imgeye dönüşmüştür. Üzerinden yıllar geçmesine rağmen halen azımsanmayacak bir dinleyici kitlesi olan metal müziğin en popüler gruplarından Iron Maiden'ın bir gün müziği bırakması halinde bile maskotun özerk bir biçimde hem grubun marka kişiliğini yaşatmaya hem de bağımsız bir figür olarak ekonomik açıdan değerli olmaya devam edeceği söylenebilir. Tüm bunlara ek olarak, doğru hamlelerle ve kitlenin beklentilerine uygun biçimde tasarlanan karakterin marka değeri açısından benzerlerinden çok önde olduğunu söylemek mümkündür.

\section{SONUÇ VE DEĞERLENDİRME}

Günümüz koşullarında yeni ve güçlü bir marka yaratmak doğru pazarlama stratejisi ve belirli bir maliyet gerektirmektedir. Markanın benzerlerinden ayrışması ve yer aldığı sektörde varlığını sürdürebilmesi için kitlesinin istek ve beklentilerini karşılaması gerekir. Hedef kitlesinin beğeni ve beklentilerine uygun biçimde tasarlanan bir marka maskotunun da zihinlerde kalıcıllı̆̆ sağlaması ancak böyle mümkün olabilmektedir. Marka ve kitlesi arasında gerçekleşen karşılıklı menfaate dayalı iletişimin en önemli bileşenleri olan hatıllanabilirlik, güven, istikrar ve samimiyet gibi unsurları destekleyici bir simge olan maskot, pazarlama ilişkisini güçlendirirken markaya olan sadakate de katkı sağlamaktadır.

Genellikle hayali bir karakter olarak karşımıza çıkan maskotlar marka kişiliğini ve tanınırlığını etkileyen önemli bir unsur olduğundan dolayı tasarlanırken hedef kitlenin kültürel, sosyal ve psikolojik özelliklerine uygun olmasına dikkat edilmelidir. Gerçek hayatta var olan karakterin yerine hayal ürünü olarak tasarlanan bir maskotun yaşlanmaması, herhangi bir telif beklentisinde olmaması, gelişen ve değişen düzene uyum sağlayabilmesi gibi daha pek çok etken markanın menfaatlerine çok uygundur.

Marka maskotları onlarca yıldır her sektörde kullanım alanı bulmuş, çeşitli markaların varlığını sürdürebilmeleri için etkin bir pazarlama aracı olarak kullanılmıştır. Geçmiş dönemde yaratılan ve bir markanın tanıtıcı yüzü haline gelmiş maskotlar incelendiğinde nitelik, yarar, değer ve kişilik anlamlarını doğru bir biçimde taşıyarak hedef kitlesine ulaştıranların markaya büyük bir fayda sağladığ1 görülmektedir. Tüm bunlara ek olarak, markanın oluşum ve gelişim sürecinin bir parçası olan maskotlar markaya değer katarken, bazı maskotların hedef kitle ile olan ilişkisinin fazlasıyla güçlenmesi ve markadan bağımsız bir biçimde şöhrete kavuşmasının da mümkün olduğu görülmektedir. Farklı sektörlerde ürün, hizmet ya da diğer biçimlerde üretim yapan markalara ait bazı maskotlar dünya çapında bir kitleye hitap eder konuma gelerek asıl işlevinden uzaklaşmıştır. Ancak bu durumun markanın çıkarlarına olduğunu söylemek de yerinde bir tespit olacaktır. 


\section{KAYNAKÇA}

Bhat, S. ve Reddy, S. (1998). Symbolic and Functional Positioning of Brands, Journal of Consumer Marketing, Cilt:15, Say1:1, 32-43. doi: 10.1108/07363769810202664

Bettinghaus, P. ve Cody, M. (1994). Persuasive Communication, Texas: Harcourt Brace College Publishers.

Can, E. (2007). Marka ve Marka Yapılandırma, Marmara Üniversitesi İ̈BF Dergisi, Cilt:22, Sayı:1, 225-237. Erişim adresi: https://dergipark.org.tr/tr/download/article-file/3702

Çerezcioğlu, A. (2013). Benzerlik ve Farklılığın Müzik Yoluyla Eşzamanlı İnşası: Anatolian Death Metal, Yedi, Say1:9, 11-21. Erişim adresi: https://dergipark.org.tr/tr/pub/yedi/issue/21842/234836

Daniels, P. (2016). The Ultimate Illustrated History of The Beast, Londra, Quarto Publishing Group.

Demireli, C., Taşkın D., Çetinkasap, B. (2014). Marka-Maskot Bütünleşmesi Turkcell Örneği, Süleyman Demirel Üniversitesi İktisadi ve İdari Bilimler Fakültesi Dergisi, Cilt:19, Sayı:1, 159-166. Erişim adresi: https://dergipark.org.tr/tr/download/article-file/194262

Discosyconciertos, (2014). Derek Riggs and Iron Maiden's Eddie the Head, Erişim adresi: https://discosyconciertos.wordpress.com/2014/01/03/derek-riggs-and-iron-maidens-eddie-the-head/

İlisulu, T. (2012). Reklamlarda Yükselen Değer: Marka Maskotları, Sanat Dergisi, Cilt:0, Sayı:20, 155169. Erişim adresi: https://dergipark.org.tr/tr/download/article-file/29040

Kayıran, C. (2015). Müziğin Görsel Kimlikleri: Hayali Karakterler ve Maskotlar, [Blog yazısı]. Erişim adresi: https://bantmag.com/muzigin-gorsel-kimlikleri-hayali-karakterler-ve-maskotlar/

Maiden-world, (t.y.). The History Of Iron Maiden's Mascot - Eddie, [Blog yazıs1]. Erişim adresi: https://maiden-world.com/articles/history-of-eddie.html

Örendirek, H. (2006). Markalaşma Sürecinin Toplam Kalite Yönetimine Etkisi ve Bir Örnek Olay Çalışması, Marmara Üniversitesi Sosyal Bilimler Enstitüsü Yüksek Lisans Tezi, İstanbul.

Özcan, B. (2014). Hayvan Semboller ve Marka Maskotlarda Kullanımı, Mustafa Kemal Üniversitesi

Sosyal Bilimler Enstitüsü Dergisi, Cilt:11, Say1:27, 53-68. Erişim adresi: https://dergipark.org.tr/tr/download/article-file/183361

Ross, H. (2006). Iron Maiden: A Photo History. Londra: Omnibus Press

Sea, N. (t.y.). The Surreal History of The MGM Lions, [Blog yazıs1]. Erişim adresi: https://www.ranker.com/list/history-of-the-mgm-lions/nida-sea

Servant, H. (2016). Hello Kitty History: Kitty White's Origin and Facts, [Blog yazısı]. Erişim adresi: https://www.johnnytimes.com/hello-kitty-history/

Uztuğ, F. (2002). Markan Kadar Konuş, Marka İletişim Stratejileri, İstanbul: Mediacat Kitapları.

Yamankaradeniz, K. (2007). Marka Olma Sanatı, İstanbul: Hayat Yayınları. 